\title{
Perencanaan Tahapan Pembangunan Fasilitas Terminal 3 Juanda Berdasarkan Pertumbuhan Penumpang
}

\author{
Gumbiratno Widiatmoko, Ervina Ahyudanari, dan Putu Artama Wiguna \\ Jurusan Teknik Sipil, Fakultas Teknik Sipil dan Perencanaan Institut Teknologi Sepuluh Nopember (ITS) \\ Jl. Arief Rahman Hakim, Surabaya 60111 Indonesia \\ e-mail: ervina@ce.its.ac.id, artama@ce.its.ac.id
}

\begin{abstract}
Abstrak-Dengan adanya pertumbuhan penduduk, perkembangan ekonomi, dan pengaruh dari ASEAN Open Sky di Indonesia, penggunaan pesawat terbang sebagai alat transportasi semakin banyak digunakan. Peningkatan demand ini merupakan pemicu dibangunnya terminal baru di Bandar Udara Juanda. Proses perencanaan dimulai dengan peramalan jumlah penumpang, untuk mengetahui pada tahun berapa jumlah penumpang mencapai 75 juta di terminal baru dan jumlah pergerakan pesawat pada tahun tersebut. Setelah itu akan dilanjutkan dengan menghitung luas ruang terminal, luas apron dan luas parkir dengan menggunakan perhitungan luas standar SNI 03-7046-2004. Setelah diketahui perkiraan tahun pembangunannya melalui peramalan, maka akan direncanakan pentahapan pembangunan terminal 3 Bandara Juanda sesuai dengan pertumbuhan penumpang pada peramalan tersebut. Peramalan dilakukan menggunakan software SPSS dan Minitab untuk mencari model ARIMA. Dengan menggunakan pemodelan ARIMA tersebut, diketahui bahwa penumpang Terminal 3 Bandara Juanda akan mencapai 75 juta pada tahun 2029. Pentahapan terminal akan dimulai pada tahun 2017 dengan pengerjaan prioritas nya adalah membangun gedung terminal, runway 1, apron grup 1, dan kantor-kantor operasional agar terminal dapat digunakan secepat mungkin. Pada tahun 2019 penerbangan domestik akan dibuka guna menanggulangi overcapacity pada Bandara Juanda. Pembangunan runway 2 dan gedung terminal bagian 2 , dilakukan pada tahun 2019 hingga pada tahun 2022 penerbangan internasional juga dapat dibuka. Akses menuju terminal yaitu pembangunan rel kereta diprioritaskan dan dimulai tahun 2022 hingga 2024. Pembangunan fasilitas arsitektur dilakukan dari tahun 2023 hingga tahun 2029 dan seluruh pembangunan sudah harus selesai pada tahun tersebut.
\end{abstract}

Kata Kunci-Peramalan, Terminal 3 Juanda, Pertumbuhan Penumpang, Pentahapan Pembangunan.

\section{PENDAHULUAN}

B ERDASARKAN Badan Pusat Statistik Indonesia (BPSI) [1], jumlah Penduduk di Indonesia pada tahun 2015 adalah sebesar 255.182.144 jiwa, namun penduduk Indonesia yang menggunakan pesawat masih mencapai $39 \%$ dari jumlah penduduk di Indonesia atau hanya 74 juta jiwa yang menggunakan pesawat di Indonesia. Dibandingkan dengan Malaysia dengan jumlah penduduk sekitar 29 juta jiwa, namun pemakaian pesawat terbangnya mencapai 48 juta, atau Singapura dengan jumlah penduduk 5,4 juta jiwa dan pemakaian pesawat terbangnya sebesar 39 juta jiwa, Indonesia masih memiliki banyak ruang untuk berkembang dalam segi transportasi udara. Seiring berkembangnya perekonomian di Indonesia maka akan semakin banyak pula masyarakat Indonesia dengan status ekonomi menengah keatas dan akan semakin banyak pula masyarakat Indonesia yang nantinya akan menggunakan pesawat. Dalam mengantisipasi terjadinya kekurangan lahan untuk pesawat maka Angkasa Pura 1 akan membangun terminal baru di Juanda, yang pada awalnya Juanda memiliki 2 terminal, direncanakan akan memiliki terminal ke-3. Tidak hanya perkembangan Indonesia yang memicu Angkasa Pura dalam pembangunan terminal 3 Bandara Juanda ini, perkembangan ASEAN dalam pasar bebasnya membuat Indonesia akan. bertambah demand terhadap pemakaian pesawat terbang ini. Pada tahun 2015 lalu, ASEAN telah memberlakukan ASEAN Open Sky, yaitu terbukanya wilayah udara antar sesama anggota ASEAN. Sebelum terjadinya kebijakan ini, barang yang akan dibawa masuk ke Indonesia dari luar negeri atau sebaliknya akan masuk ke tiga bandara pemegang peta kargo di ASEAN terlebih dahulu, yaitu Singapura, Thailand, dan Vietnam. Dengan adanya kebijakan ini akhirnya barang yang akan keluar atau masuk Indonesia yang menggunakan transportasi udara dapat langsung ke Negara tujuannya. ASEAN Open Sky ini akan membebaskan maskapai, pengelola bandar udara, pengatur penerbangan di darat (ground handling), hingga pengatur lalu-lintas penerbangan untuk bebas berusaha dan berekspansi.

Setelah melihat kondisi tersebut, Angkasa Pura 1 memutuskan untuk membangun suatu terminal baru yang mampu menampung penumpang sebesar 75 juta jiwa. Jumlah tersebut merupakan pertimbangan dari Angkasa Pura yang telah melakukan studi pendahuluan dari perkembangan pemakaian pesawat terbang di Indonesia oleh faktor internal, seperti pertumbuhan ekonomi, kemudahaan akses, dan juga faktor eksternal yang berupa semakin bertambahnya pengunjung internasional karena adanya kemudahan akses oleh ASEAN Open Sky tersebut.

Secara garis besar, tujuan yang diharapkan dari perencanaan yang akan dilakukan adalah mengetahui tahun berapa Terminal 3 Bandara Juanda harus selesai dibangun, mengetahui luas Terminal 3 Bandara Juanda yang dibutuhkan sesuai dengan SNI, mengetahui luas apron terminal 3, dan merencanakan pentahapan yang perlu dilakukan dalam pembangunan.

\section{TINJAUAN PUSTAKA}

\section{A. Peramalan}

Peramalan / forecasting adalah upaya memperkirakan apa yang terjadi di masa depan, berbasis pada metode ilmiah (ilmu dan teknologi) serta dilakukan secara sistematis. Rentang wakru kegiatan peramalan dalm praktek sangat bervariasi. Peramalan yang berbasis waktu dapat dibagi menjadi jangka pendek (satu hari sampai satu tahun), jangka menengah (satu musim sampai 2 tahun), atau jangka panjang (minimal 5 tahun). Adapun tahapan dalam peramalan adalah perumusan masalah dan pengumpulan data, persiapan data, 
membangun model, implementasi model, dan evaluasi forecasting [2].

\section{B. Luas Standar Fasilitas Terminal}

Untuk perencanaan kasar dari bandara dipakai luasan standar pada bandara sesuai SNI 03-7046-2004 [3], akan dijelaskan dan diimplemtasikan pada hasil analisis. Basis yang perlu diketahui dalam perhitungan luas sesuai dengan SNI adalah presentase TPHP terhadap jumlah penumpang per tahun. Faktor-faktor yang dibutuhkan dalam menghitung luas fasilitas terminal sesuai SNI terdapat pada Tabel 1 dan Tabel 2.

Tabel 1.

Perbandingan Jumlah Penumpang per Tahun dengan Presentasi TPHP-nya [4]

\begin{tabular}{cc}
\hline \hline Jumlah Penumpang per Tahun & TPHP (\%) \\
\hline > 30 Juta & 0.035 \\
20 Juta $<$ x $<$ 29 Juta & 0.040 \\
10 Juta $<$ x $<$ 19 Juta & 0.045 \\
1 Juta $<$ x $<$ Juta & 0.050 \\
500 ribu $<x<99$ ribu & 0.080 \\
100 ribu $<x<499$ ribu & 0.130 \\
$<100$ ribu & 0.200 \\
\hline
\end{tabular}

Tabel 2.

Sirkulasi Ruang dan Kecepatan [4]

\begin{tabular}{|c|c|c|c|}
\hline Lokasi & Troli & $\begin{array}{c}\text { Kebutuhan ruang m2 per } \\
\text { penumpang }\end{array}$ & $\begin{array}{c}\text { Kecepatan } \\
\text { m/dtk }\end{array}$ \\
\hline Sisi Udara & Tidak ada & 1,5 & 1,3 \\
\hline Setelah Check-In & Sedikit & 1,8 & 1,1 \\
\hline Area Keberangkatan & Banyak & 2,3 & 0,9 \\
\hline
\end{tabular}

\section{Apron}

Apron adalah bagian dari lapangan gerak darat suatu Bandar udara yang berfungsi untuk menaik turunkan penumpang dan muatan, pengisian bahan bakar, parkir dan persiapan esawat terbang sebelum melanjutkan perjalanan. Apron terdiri dari temapat parkir pesawat (aircraft gates, aircraft stands atau ramps) dan jalur khusus untuk sirkulasi pesawat masuk dan keluar tempat parkir (taxilane). Daerah apron biasanya tidak dapat diakses oleh umum, diperlukan sejenis izin khusus untuk dapat memasuki area ini. Ukuran apron pada sebuah Bandar udara dipengaruhi oleh beberapa hal, yaitu, jumlah aircraft gate, ukuran gate, luas areal yang diperlukan untuk maneuver pesawat di gate, dan sistem serta tipe parkir pesawat

Langkah pertama yang dilakukan untuk menghitung luas apron adalah mencari peak month ratio, peak day ratio, dan peak hour ratio pada data historis. Pencarian rasio ini dapat dilakukan dengan melihat data pesawat pada tahun-tahun sebelumnya dan mencari ratio untuk masing-masing bulan, hari, dan jam nya. Rumus (1), (2), dan (3) merupakan rumusrumus yang digunakan untuk mencari rasio.

$R_{\text {month }}=N_{\text {bulan yang ditinjau }} / N_{\text {tahun yang ditinjau }}$

$R_{\text {Day }}=N_{\text {hari yang ditinjau }} / N_{\text {bulan yang ditinjau }}$

$R_{\text {hour }}=N_{\text {jam yang ditinjau }} / N_{\text {hari yang ditinjau }}$

Ukuran dan letak gate harus direncanakan dengan memperhatikan karakter pesawat yang menggunakan gate tersebut seperti lebar sayap, panajang, radius belok pesawat,dan juga area yang diperlukan oleh kendaraankendaraan yang menyediakan suatu servis untuk pesawat selama berada di gate.Untuk menjamin keselamatan pesawat di daratan, ICAO dan FAA juga menerapkan persyaratan jarak minimum antara pesawat terbang yang sedang parkir diapron, juga antara pesawat terbang dengan bangunan atau obyek tetap lainya yang berada di apron berdasarkan jarak sayap pesawat / wing tip clereance.
Rumus (4) merupakan Gate position yang menggunakan rumus Horrenjeff [5].

$$
\mathrm{G}=(\mathrm{V} \times \mathrm{T}) / \mathrm{U}
$$

Dimana :

$\mathrm{V}=$ Volume jumlah pesawat datang dan berangkat (penerbangan/jam)

$\mathrm{T}=$ Gate occupancy time (jam)

$\mathrm{U}=$ Faktor penggunaan $(0,6-0,9)$

Ketetapan untuk jarak bebas pesawat bedasarkan FAA terdapat pada Tabel 3.

Tabel 3 .

Hubungan Bentang Sayap Pesawat dengan jarak bebas pesawat [4]

\begin{tabular}{cccc}
\hline \hline \multicolumn{2}{c}{$\begin{array}{c}\text { Bentang Sayap Pesawat } \\
\text { Meter }\end{array}$} & Feet & Jarak Bebas \\
\hline$<15$ & $<49$ & 2 & Feet \\
$15-24$ & $49-79$ & 3 & 10 \\
$24-36$ & $79-118$ & 4,5 & 10 \\
$36-52$ & $118-171$ & 7,5 & 15 \\
$>52$ & $>171$ & 7,5 & 25 \\
\hline \hline
\end{tabular}

\section{Tipe Pesawat}

Boeing 739 [6] adalah sebuah pesawat penumpang sipil (airliner) komersial untuk penerbangan jarak dekat dan jauh. Pertama kali dibuat pada tahun 2006, dan resmi mengudara pada 2007, Boeing 739 Extended Range dioperasikan pertama kali oleh maskapai penerbangan asal Indonesia yaitu Lion Air. Tipe pesawat B 739 ini merupakan pesawat kelas C.

- wingspan: $34,3 \mathrm{~m}$

- Panjang: 42,1 m

Boeing 757 [6] adalah pesawat penumpang sipil jarak menengah dibuat oleh Boeing Commercial Airplanes. Pesawat ini didesain bagi Eastern Airlines dan British Airways untuk menggantikan Boeing 727 dan mulai memasuki masa dinas pada tahun 1983. Produksi 757 berakhir pada bulan 28 Oktober 2004 setelah diproduksi 1,050 pesawat untuk 54 pelanggan. Pesawat kelas D.

- wingspan: $38 \mathrm{~m}$

- Panjang: 47,3 m

Airbus A330 [6] merupakan sebuah pesawat terbang jet sipil komersial bermesin ganda (twinjet) jarak-menengahhingga-jauh berkapasitas besar, berbadan lebar. Pesawat ini dibuat pada waktu yang sama dengan Airbus A340 bermesin empat. Diperkirakan bahwa pesawat ini digantikan oleh Airbus A350. Pesawat ini dikembangkan dari Airbus A300, pesawat badan lebar perdana Airbus yang sangat sukses di pasaran. Tipe pesawat A 330 merupakan kelas pesawat E.

- wingspan: $60,3 \mathrm{~m}$

- Panjang: 63,60 m

Airbus A380 [6] yang diproduksi oleh Airbus S.A.S. adalah sebuah pesawat berbadan lebar dua tingkat, dengan empat mesin yang mampu memuat 850 penumpang dalam konfigurasi satu kelas atau 555 penumpang dalam konfigurasi tiga kelas. Pesawat ini melaksanakan penerbangan perdana pada 27 April 2005 dan telah memulai penerbangan komersial pada akhir tahun 2007 setelah ditunda beberapa kali. Pesawat ini juga merupakan pesawat komersial (pesawat penumpang) terbesar yang pernah dibuat (dijuluki Superjumbo).

- wingspan: 79,8 m

- Panjang: $73 \mathrm{~m}$ 


\section{E. Fasilitas Utama Bandara}

Adapun fasilitas utama untuk operasional suatu bandara adalah sebagai berikut:

1. Runway

2. Apron

3. Air Traffic Controller

4. Unit penanggulangan kecelakaan

5. Fuel service

6. Terminal bandar udara

7. Curb

8. Parkir kendaraan

\section{METODOLOGI}

Metode yang digunakan dalam modifikasi perencanaan dinyatakan dalam diagram alur yang terdapat pada gambar 1 .

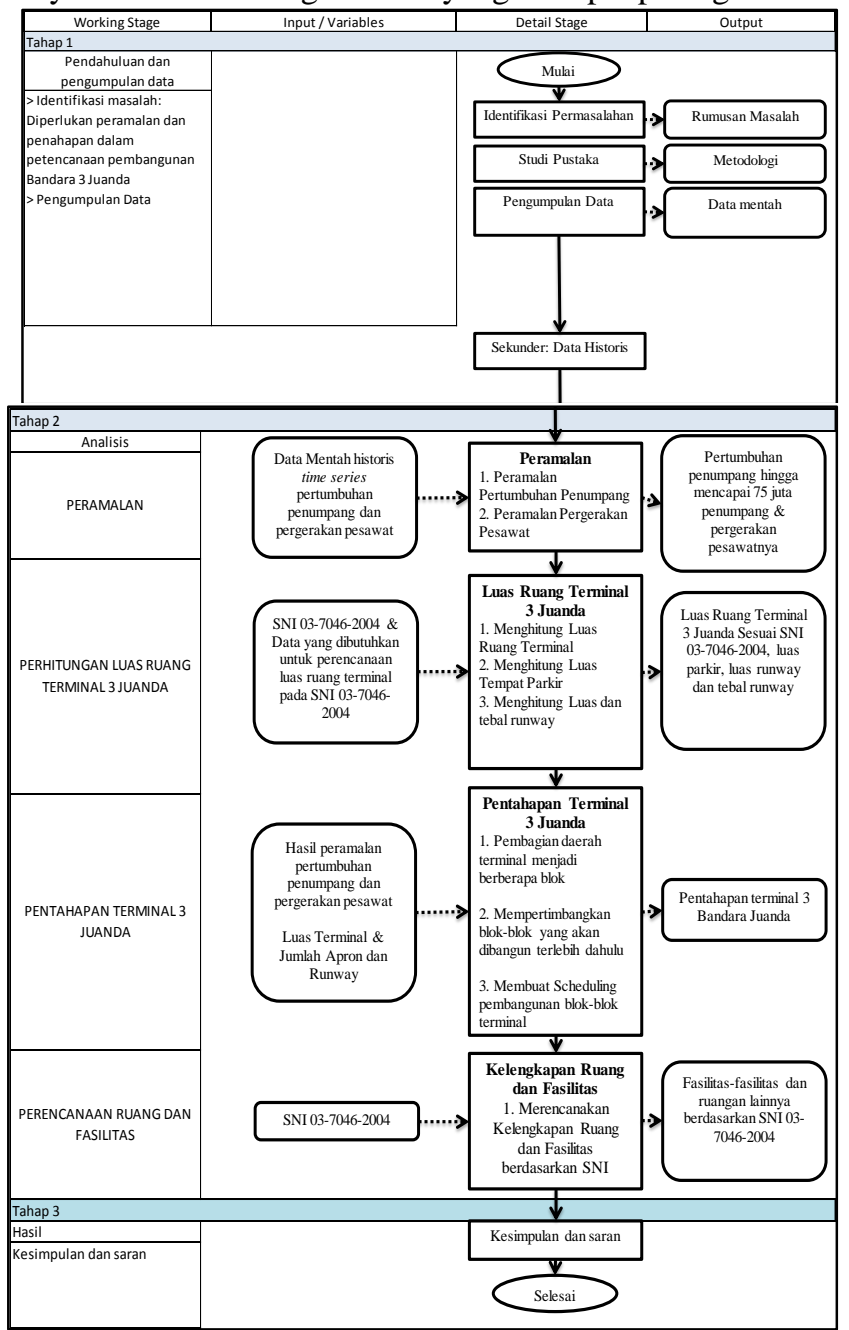

Gambar 1. Diagram Alur Metodologi Perencanaan

Subjek dari peramalan adalah jumlah penumpang, pergerakan pesawat tipe B 739, B757, dan A330 sebagai perwakilan dari pergerakan pesawat tipe C,D, dan E. Untuk perhitungan apron pun menggunakan tipe pesawat tersebut ditambah dengan tipe pesawat A380 sebagai perwakilan dari tipe pesawat kelas F.

\section{ANALISIS DAN PEMBAHASAN}

\section{A. Peramalan Penumpang dan Pesawat}

Peramalan akan dilakukan menggunakan Minitab untuk mendapatkan model ARIMA, kemudian dimasukkan kedalam SPSS untuk mendapatkan hasil peramalan yang diinginkan. Untuk melakukan peramalan, perlu adanya data historis yang dalam penelitian ini merupakan data time series. Dari data tersebut akan diolah menggunakan Minitab dan SPSS. Perlu diketahui bahwa 75 juta penumpang akan digunakan dalam perencanaan pada terminal 3 saja, oleh karena itu total penumpang yang nantinya diharapkan pada peramalan ini adalah ketika pertumbuhan penumpang mencapai 75 juta penumpang ditambah penumpang eksisting yang ada pada terminal 1 dan 2, yaitu 18.911.256 penumpang. Maka peramalan akan dilakukan dengan mencari kapan tahun terjadinya penumpang dengan jumlah 93.911.256 penumpang. Hasil dari peramalan penumpang dan pergerakan pesawat dengan SPSS dan Minitab terdapat pada Tabel 4.

Tabel 4.

Hasil Peramalan Penumpang

\begin{tabular}{cccc}
\hline \hline Tahun & Jumlah Penumpang & Tahun & Jumlah Penumpang \\
\hline 2015 & $17,871,799$ & 2023 & $54,682,541$ \\
2016 & $21,543,020$ & 2024 & $60,479,756$ \\
2017 & $25,479,989$ & 2025 & $66,542,720$ \\
2018 & $29,682,708$ & 2026 & $72,871,433$ \\
2019 & $34,151,176$ & 2027 & $79,465,895$ \\
2020 & $38,885,394$ & 2028 & $86,326,106$ \\
2021 & $43,885,360$ & 2029 & $93,452,067$ \\
2022 & $49,151,076$ & & \\
\hline
\end{tabular}

Didapat dari peramalan jumlah penumpang dengan menggunakan SPSS bahwa Terminal 3 Bandara Juanda akan mencapai 75 Juta penumpang pada tahun 2029. Untuk selanjutnya akan dihitung pergerakan pesawat pada tahun rencana untuk masing-masing tipe yang terdapat pada Tabel 5, Tabel 6, dan Tabel 7.

Selanjutnya dilakukan pengecekan hasil peramalan pada tahun 2013 dengan data eksisting pada tahun 2013. Didapat perbedaan dari hasil ramalan dengan data eksiting tidak lebih dari $15 \%$, oleh karena itu hasil peramalan dapat digunakan. Tabel 5.

Hasil Peramalan Pergerakan Pesawat B 739 dengan SPSS

\begin{tabular}{cccc}
\hline \hline \multirow{2}{*}{ Tahun } & Jumlah Pesawat B & \multirow{2}{*}{ Tahun } & Jumlah Pesawat B \\
& $\mathbf{7 3 9}$ & $\mathbf{7 3 9}$ \\
\hline $\mathbf{2 0 1 3}$ & 9,013 & $\mathbf{2 0 2 2}$ & 17,760 \\
$\mathbf{2 0 1 4}$ & 9,376 & $\mathbf{2 0 2 3}$ & 18,834 \\
$\mathbf{2 0 1 5}$ & 10,159 & $\mathbf{2 0 2 4}$ & 19,908 \\
$\mathbf{2 0 1 6}$ & 11,354 & $\mathbf{2 0 2 5}$ & 20,981 \\
$\mathbf{2 0 1 7}$ & 12,377 & $\mathbf{2 0 2 6}$ & 22,055 \\
$\mathbf{2 0 1 8}$ & 13,472 & $\mathbf{2 0 2 7}$ & 23,129 \\
$\mathbf{2 0 1 9}$ & 14,537 & $\mathbf{2 0 2 8}$ & 24,203 \\
$\mathbf{2 0 2 0}$ & 15,614 & $\mathbf{2 0 2 9}$ & 25,276 \\
$\mathbf{2 0 2 1}$ & 16,686 & & \\
\hline \hline
\end{tabular}

Tabel 6.

Hasil Peramalan Pergerakan Pesawat B 757 dengan SPSS

\begin{tabular}{cccc}
\hline \hline \multirow{2}{*}{ Tahun } & Jumlah Pesawat B & \multirow{2}{*}{ Tahun } & Jumlah Pesawat B \\
& $\mathbf{7 5 7}$ & & $\mathbf{7 5 7}$ \\
\hline $\mathbf{2 0 1 3}$ & 4,137 & $\mathbf{2 0 2 2}$ & 6,489 \\
$\mathbf{2 0 1 4}$ & 3,418 & $\mathbf{2 0 2 3}$ & 6,872 \\
$\mathbf{2 0 1 5}$ & 3,802 & $\mathbf{2 0 2 4}$ & 7,256 \\
$\mathbf{2 0 1 6}$ & 4,186 & $\mathbf{2 0 2 5}$ & 7,640 \\
$\mathbf{2 0 1 7}$ & 4,569 & $\mathbf{2 0 2 6}$ & 8,024 \\
$\mathbf{2 0 1 8}$ & 4,953 & $\mathbf{2 0 2 7}$ & 8,408 \\
$\mathbf{2 0 1 9}$ & 5,337 & $\mathbf{2 0 2 8}$ & 8,791 \\
$\mathbf{2 0 2 0}$ & 5,721 & $\mathbf{2 0 2 9}$ & 9,175 \\
$\mathbf{2 0 2 1}$ & 6,105 & & \\
\hline \hline
\end{tabular}

Tabel 7.

Hasil Peramalan Pergerakan Pesawat A 330 dengan SPSS 


\begin{tabular}{cccc}
\hline \hline \multirow{2}{*}{ Tahun } & Jumlah Pesawat A & \multirow{2}{*}{ Tahun } & Jumlah Pesawat A \\
& $\mathbf{3 3 0}$ & $\mathbf{3 3 0}$ \\
\hline $\mathbf{2 0 1 3}$ & 691 & $\mathbf{2 0 2 2}$ & 1,535 \\
$\mathbf{2 0 1 4}$ & 803 & $\mathbf{2 0 2 3}$ & 1,625 \\
$\mathbf{2 0 1 5}$ & 901 & $\mathbf{2 0 2 4}$ & 1,716 \\
$\mathbf{2 0 1 6}$ & 993 & $\mathbf{2 0 2 5}$ & 1,806 \\
$\mathbf{2 0 1 7}$ & 1,084 & $\mathbf{2 0 2 6}$ & 1,896 \\
$\mathbf{2 0 1 8}$ & 1,174 & $\mathbf{2 0 2 7}$ & 1,986 \\
$\mathbf{2 0 1 9}$ & 1,265 & $\mathbf{2 0 2 8}$ & 2,076 \\
$\mathbf{2 0 2 0}$ & 1,355 & $\mathbf{2 0 2 9}$ & 2,167 \\
$\mathbf{2 0 2 1}$ & 1,445 & & \\
\hline \hline
\end{tabular}

\section{B. Perhitungan Luas Terminal}

Dalam merencanakan luas dan komposisi ruang perlu berberapa data yang akan dimasukkan dalam perumusan yang sudah ditetapkan oleh SNI 03-7046-2004, Hasil perumusan luas terminal terdapat pada Tabel 8.

Tabel 8.

Hasil Perhitungan Luas Bandara

\begin{tabular}{|c|c|c|}
\hline Jenis Fasilitas & Kebutuhan Ruang & Hasil \\
\hline Kerb Keberangkatan & 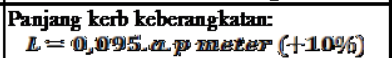 & $1.047 \mathrm{~m}$ \\
\hline Hall Keberangkatan & 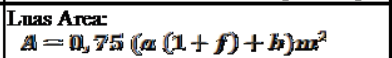 & $36.028 \mathrm{~m}^{23}$ \\
\hline Counter Check in & 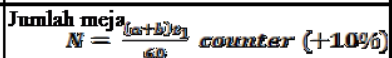 & 827 comnter \\
\hline Area Check in & 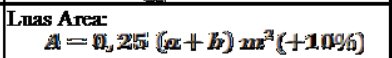 & $4.134 m^{23}$ \\
\hline Pemeriksaan Passport Berangkat & 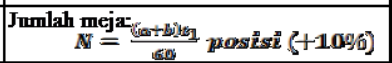 & 827 meja \\
\hline Pemeriksaan Passport Datang & 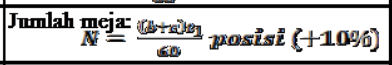 & 827 meja \\
\hline \begin{tabular}{|l} 
Area Pemeriksaan Passport \\
\end{tabular} & Lnas Area $\mathrm{A}=\mathbf{0}, 225(\mathrm{~b}+\boldsymbol{c}) \mathrm{m}^{2}$ & $4.134 \mathrm{mi}^{22}$ \\
\hline Pemeriksaan Security (terpusat) & 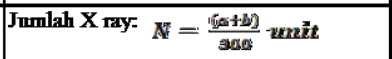 & $55 X-r a y$ \\
\hline $\begin{array}{l}\text { Pemeriksaan Secmrity (Gate Hold } \\
\text { Room) }\end{array}$ & Jumlah X ray $N=\mathbb{0}, 2 \frac{m}{g-h}$ wmit & $6.240 X$-rayss \\
\hline Gate Hold Room & Lnas Arear $\quad A=(m, s) m^{2}$ & $957 \mathrm{mi}^{32}$ \\
\hline \begin{tabular}{|l|} 
Ruang Tunggu Keberangkatan \\
(behmm termasuk mang konsesi)
\end{tabular} & 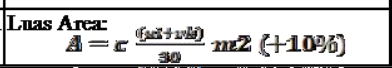 & $49.219 \mathrm{mB}^{2}$ \\
\hline \begin{tabular}{|l} 
Baggage claim area (behm \\
termasuk claim device)
\end{tabular} & Luas arear $\quad A=0,9 / \mathrm{min}(+10 \%)$ & $14.175 \mathrm{~m}^{32}$ \\
\hline Baggage claim device & 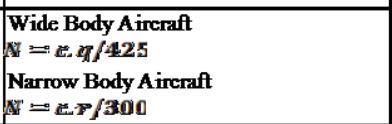 & $\begin{array}{l}13 \text { devices } \\
34 \text { devices }\end{array}$ \\
\hline Kerb Kedatangan & 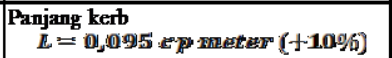 & $1.047 \mathrm{~m}$ \\
\hline $\begin{array}{l}\text { Hall kedatangan (behm termasuk } \\
\text { nang konsesi) }\end{array}$ & $\begin{array}{l}\text { Luas area } \\
A=01,375(b+c+2 e f) m 2(+10 \%)\end{array}$ & $29.827 \mathrm{~mL}^{2 \mathrm{z}}$ \\
\hline
\end{tabular}

\section{Perencanaan Luas Apron}

Untuk perhitungan luas apron ini akan direncanakan dengan menggunakan pergerakan dan ukuran pesawat B 739, B 757, A 330, dan A 380 pada tahun 2029. Langkah pertama yang dilakukan adalah menghitung peak hour pesawat pada pergerakan pesawat di tahun rencana, dengan menghitung peak month ratio, peak day ratio dan peak hour ratio pada data histori akan didapat peak hour pada tahun rencana dengan mengalikan pergerakan pesawat pada tahun rencana dengan masing-masing rasio. Hasil perhitungan rasio untuk masing-masing tipe pesawat terdapat pada Tabel 9.

Tabel 9.
Rasio Pergerakan Pesawat untuk Masing-masing Tipe

\begin{tabular}{lclr}
\hline \multicolumn{2}{c}{ Pesawat Tipe B 739 } & \multicolumn{2}{c}{ Pesawat Tipe A 330 } \\
Jenis Ratio & Ratio & Jenis Ratio & \multicolumn{1}{c}{ Ratio } \\
\hline Peak Month Ratio & 0.1031 & Peak Month Ratio & 0.129098361 \\
Peak Day Ratio & 0.03769 & Peak Day Ratio & 0.061538462 \\
Peak Hour Ratio & 0.11765 & Peak Hour Ratio & 0.5 \\
$\quad$ Pesawat Tipe B 757 & & \\
Jenis Ratio & Ratio & & \\
\hline Peak Month Ratio & 0.09929 & & \\
\hline \hline
\end{tabular}

\begin{tabular}{lr} 
Peak Day Ratio & 0.05263 \\
Peak Hour Ratio & 0.2 \\
\hline
\end{tabular}

Dari ratio diatas akan dikalikan dengan pergerakan pesawat per tahunnya untuk masing-masing tipe, sehingga didapat pergerakan pesawat per tahun untuk masing-masing tipe pada tahun rencana, yaitu 2029. Setelah itu hasil pergerakan pesawat per tahun tersebut akan dikalikan dengan peak day ratio dan hasilnya akan dikalikan dengan peak hour ratio. Sehingga didapat peak hour pada masing-masing tipe di tahun 2029. Waktu puncak pergerakan pesawat terdapat pada Tabel 10 .

Tabel 10.

Waktu Puncak Pergerakan Pesawat

\begin{tabular}{|c|c|c|}
\hline \multicolumn{3}{|c|}{ Pesawat Tipe B 739} \\
\hline $\begin{array}{c}\text { Peak Month } 2029 \\
\text { Peak Day } 2029 \\
\text { Peak Hour 2029 } \\
\end{array}$ & $\begin{array}{c}2607 \\
99 \\
12 \\
\end{array}$ & $\begin{array}{l}\text { Pergerakan } \\
\text { Pergerakan } \\
\text { Pergerakan } \\
\end{array}$ \\
\hline \multicolumn{3}{|c|}{ Pesawat Tipe B 757} \\
\hline $\begin{array}{c}\text { Peak Month } 2029 \\
\text { Peak Day } 2029 \\
\text { Peak Hour } 2029 \\
\end{array}$ & $\begin{array}{c}912 \\
48 \\
10 \\
\end{array}$ & $\begin{array}{l}\text { Pergerakan } \\
\text { Pergerakan } \\
\text { Pergerakan }\end{array}$ \\
\hline \multicolumn{3}{|c|}{ Pesawat Tipe A 330} \\
\hline $\begin{array}{c}\text { Peak Month } 2029 \\
\text { Peak Day } 2029 \\
\text { Peak Hour } 2029\end{array}$ & $\begin{array}{c}280 \\
18 \\
9 \\
\end{array}$ & $\begin{array}{l}\text { Pergerakan } \\
\text { Pergerakan } \\
\text { Pergerakan }\end{array}$ \\
\hline
\end{tabular}

Untuk pertimbangan penggunaan pesawat tipe A380 dalam perencanaan apron hanya sebatas mengetahui perkiraan pergerakan pesawat tersebut, karena untuk tipe ini tidak pernah ada data historisnya di Indonesia dan tidak bisa diramalkan. Oleh karena itu penulis menggunakan presentase pergerakan pesawat tipe A380 di negara lain sebagai pedoman untuk menentukan jumlah pergerakan pesawat tipe ini. Hasil peninjauan dari pergerakan pesawat tipe A380 di negara lain terdapat pada Tabel 11.

Dari Tabel 11 didapat bahwa rata-rata pergerakan pesawat tipe A380 adalah 1,23\% dari total pergerakan pesawat per tahun nya. Dari presentase tersebut dapat dikalkulasikan untuk pergerakan pesawat tipe A380 pada tahun 2029 adalah $1,23 \% \times(9.176+25.277+2.167)=451$ pergerakan per tahun.

Tabel 11.

Pergerakan Pesawat Tipe A380 di Negara Lain

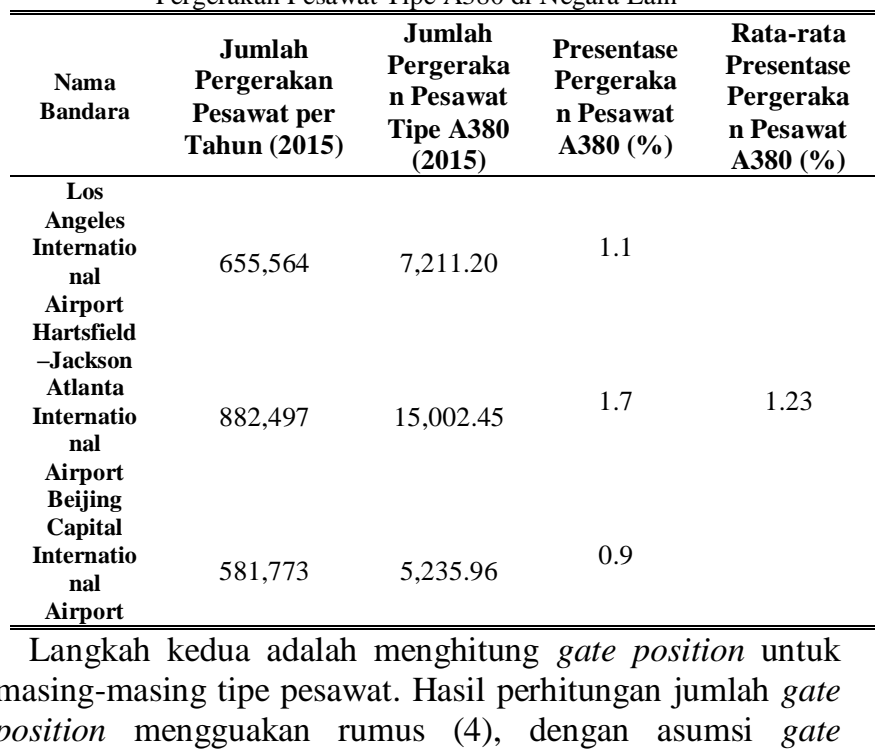


occupancy time selama 45 menit dan faktor penggunaan gate adalah 0,8, ditujukkan pada Tabel 12 .

Tabel 12.

Perhitungan Jumlah Gate Position

\begin{tabular}{lll}
\hline \hline Tipe Pesawat & Perhitungan & Hasil \\
\hline Boeing 739 & $(12 \times(45 / 60)) / 0,8$ & 12 Gate \\
Boeing 757 & $(10 \times(45 / 60)) / 0,8$ & 10 Gate \\
Airbus 330 & $(9 \times(45 / 60)) / 0,8$ & 9 Gate \\
\hline \hline
\end{tabular}

Langkah ketiga adalah mengitung luas apron. Untuk merencanakan luas apron, karakteristik pesawat yang akan dijadikan acuan dalam perencanaan luas apron adalah pesawat yang diramalkan, dengan spesifikasi badan pesawat yang ada juga menunjukkan data yang dibutuhkan untuk menghitung luas apron diantaranya yaitu: area bebas antara ujung pesawat dengan gedung terminal $(\mathrm{Cb})$ dan antar ujung sayap $(\mathrm{Cw})$, area bebas untuk mobil service pesawat (Asv), dan area traktor sebagai alat bantu push-out pesawat (P). Contoh perhitungan luas apron pesawat terdapat pada Tabel 13.

Tabel 13.

Perhitungan Luas Apron

\begin{tabular}{ccc}
\hline \multicolumn{3}{c}{ Luas apron untuk tipe B 739 } \\
\hline Panjang Apron & Banyak Gate & Lebar Gate \\
$\mathrm{L}+\mathrm{Cb}+\mathrm{Asv}+\mathrm{P}$ & $\mathrm{G}$ & $\mathrm{W}+(0,1 \times \mathrm{W})+\mathrm{Cw})$ \\
$42,1+7,5+3,7+$ & 12 & $(34,3+(0,1 \times 34,3)$ \\
9,2 & 12 Gate & $+7,5))$ \\
$62.5 \mathrm{~m}$ & Luas Satu Apron B 739 \\
& 62,5 m x 45,23 m & \\
& Luas Total Apron B 739 \\
& $62,5 \mathrm{~m} \times 12$ gate $\mathrm{m} 45,23 \mathrm{~m}$ \\
\hline \hline
\end{tabular}

Luas apron untuk tipe B 757 diperoleh sebesar $33,337 \mathrm{~m}^{2}$. Sedangkan Luas apron untuk tipe A 330 diperoleh sebesar $55,816 \mathrm{~m}^{2}$.

\section{Pentahapan Terminal}

Langkah pertama untuk melakukan pentahapan terminal adalah membagi berberapa bangunan menjadi blok bangunan dengan kriteria fungsi yang sama. Hasil pembagian blok bangunan terdapat pada Gambar 2.

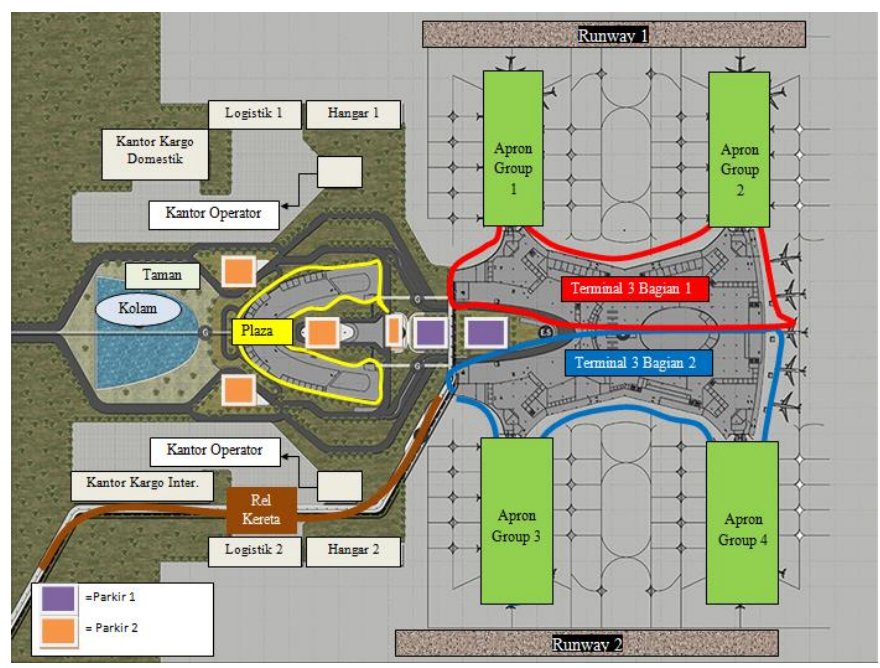

Gambar 2. Pembagian Blok Bangunan Terminal 3

Langkah kedua adalah melakukan pertimbangan untuk menentukan prioritas pembangunan, durasi pembangunan, dan kebutuhan pembangunan. Pertimbangan-pertimbangan tersebut menghasilkan berberapa keputusan, diantara lain adalah untuk membangun runway tambahan apabila pembangunan runway sebelumnya dengan tahun yang ditinjau memiliki selisih penumpang sebesar 22 juta penumpang, lalu untuk membangun runway tambahan apabila pembangunan runway sebelumnya dengan tahun yang ditinjau memiliki selisih penumpang sebesar 163 ribu pergerakan pesawat. Apabila overcapacity mencapai dua kali lipat maka pembangunan terminal atau runway baru untuk penanggulanan overcapacity sudah harus selesai, prioritas dalam pembangunan adalah bangunan utama dalam operasional suatu bandara, yaitu terminal, apron, taxiway, ATC (Air Traffic Control), dan runway untuk sisi udara dan curb, terminal serta parkir kendaraan untuk sisi darat. Untuk pembangunan runway akan direncanakan selama 3 tahun, pembangunan terminal secara keseluruhan selama 7 tahun, pembangunan apron per grup selama 2 tahun, dan pembangunan rel kereta selama 3 tahun

Hasil pentahapan untuk pembangunan Terminal 3 Bandara Juanda terdapat pada Tabel 14.

Tabel 14.

Pentahapan Terminal 3 Bandara Juanda

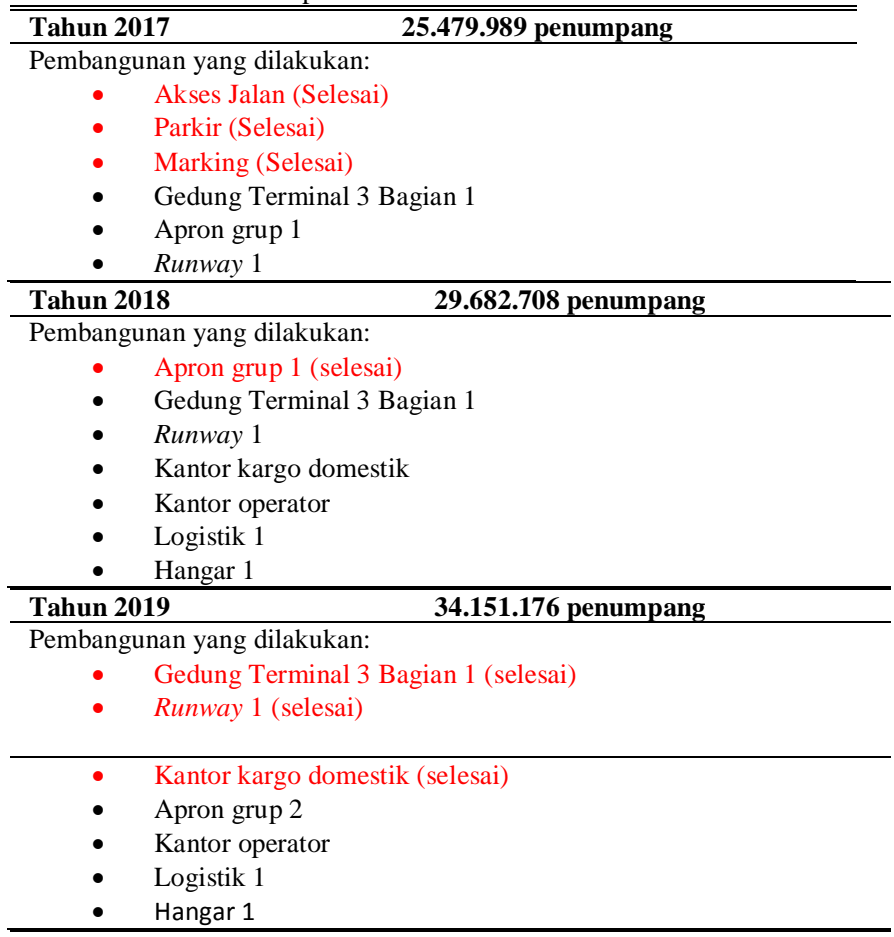

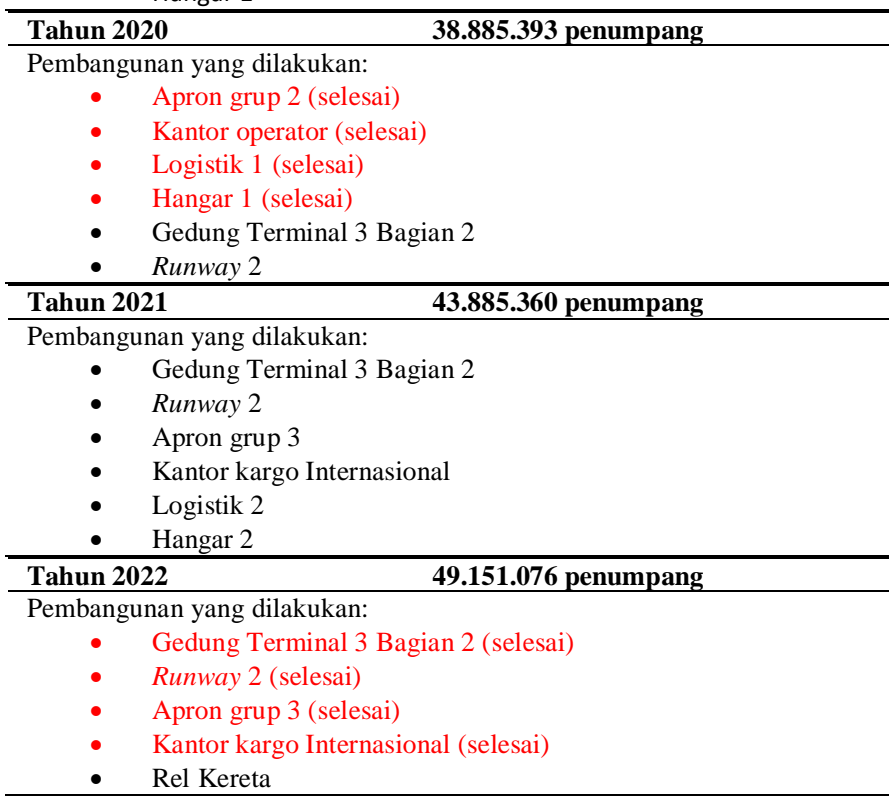




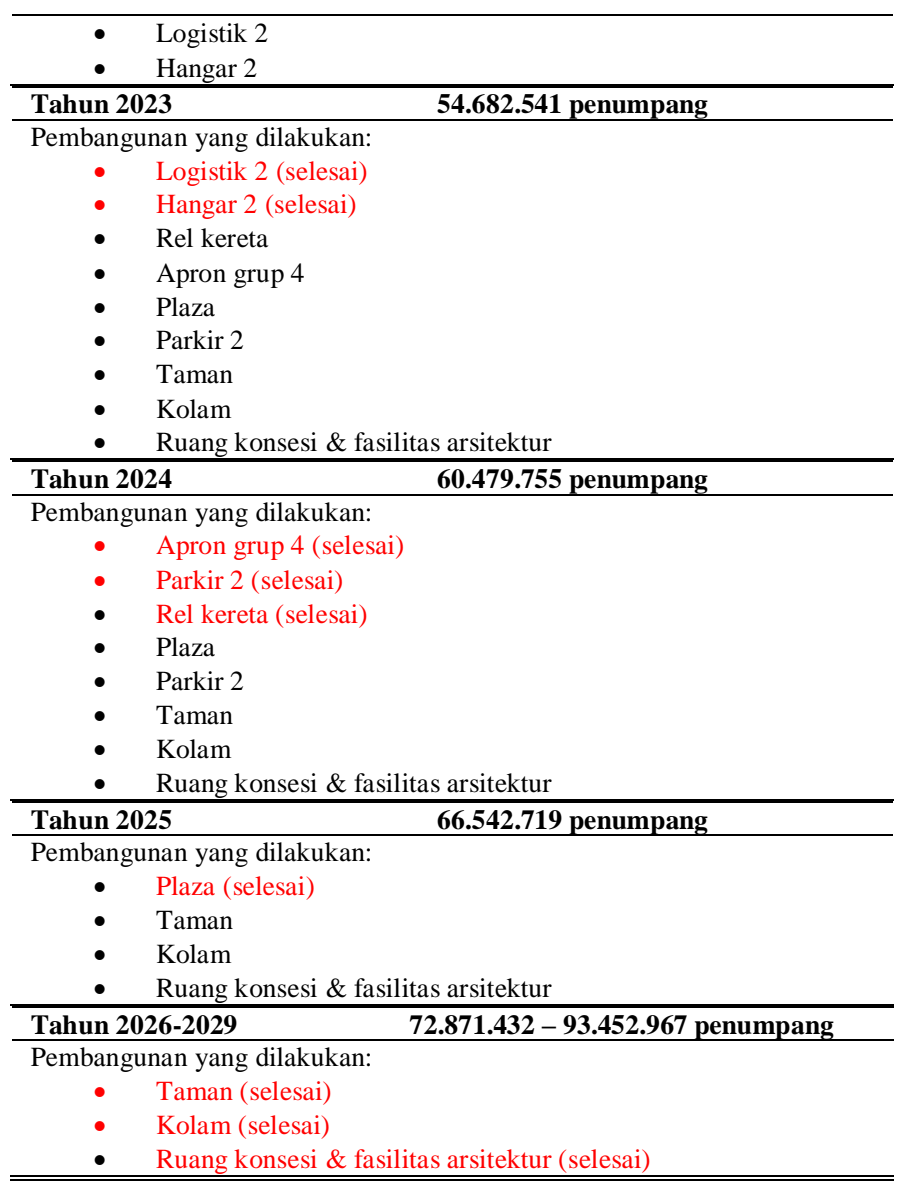

\section{KESIMPULAN}

Berdasarkan hasil analisis yang telah dilakukan, dapat diperoleh beberapa kesimpulan, antara lain:

1) Penumpang pada Terminal 3 Bandara Juanda diperkirakan akan memiliki 75 juta penumpang paling cepat pada tahun 2029 berdasarkan peramalan menggunakan data time series dengan model ARIMA. Dengan kata lain, Terminal 3 Bandara Juanda harus sudah selesai pada tahun 2029 .

2) Perencanaan luas fasilitas utama terminal 3 yang ada di SNI akan memiliki total luas $875.000 \mathrm{~m}^{2}$. Dengan jumlah meja untuk check in dan pemeriksaan passport masing-masing 827 meja. Panjang kerb keberangkatan sama dengan kerb kedatangan $1.047 \mathrm{~m}$, dan kerb.

3) Pada tahun 2029 pergerakan pesawat yang diramalkan diperkirakan untuk tipe B739 akan memiliki 25.277 pergerakan, dengan luas apron $33.923 \mathrm{~m}^{2}$. Untuk tipe B757 akan memiliki 9.175 pergerakan, dengan luas apron $33.377 \mathrm{~m}^{2}$. Dan untuk tipe A330 akan memiliki 2167 pergerakan, dengan luas apron $55.816 \mathrm{~m}^{2}$.

4) Pentahapan terminal akan dimulai pada tahun 2017 dengan pengerjaan prioritas nya adalah membangun gedung terminal, runway 1, apron grup 1, dan kantorkantor operasional agar terminal dapat digunakan secepat mungkin. Pada tahun 2019 penerbangan domestik akan dibuka guna menanggulangi overcapacity pada Bandara Juanda. Pembangunan runway 2 dan gedung terminal bagian 2, diakukan pada tahun 2019 hingga pada tahun 2022 penerbangan internasional juga dapat dibuka. Akses menuju terminal yaitu pembangunan rel kereta diprioritaskan dan dimulai tahun 2022 hingga 2024, sedangkan pembangunan fasilitas arsitektur dilakukan dari tahun
2023 hingga tahun 2029 dan seluruh pembangunan sudah harus selesai.

\section{DAFTAR PUSTAKA}

[1] Badan Pusat Statistik Indonesia (2005-2014). Indonesia Dalam Angka. Surabaya.

[2] Markidakis, S. 1995. Metode dan Aplikasi Peramalan, Diterjemahkan oleh: Erangga , Jakarta

[3] Badan Standarisasi Nasional 2004. SNI.03-7046-2004: Terminal Penumpang Bandara Udara

[4] Ashford, N.J., Mumayiz, S., dan Wright, P.H. 2011. Airport Engineering Planning, Design and Development of $21^{\text {st }}$ Century Airports. Edisi ke 4. John Wiley \& Sons, Inc.

[5] Horonjeff, R., McKelvey, F.X., Sproule, W.J., Young, S.B. 2010 Planning and Design of Airport, Edisi ke 5. The McGraw-Hill, inc.

[6] -,2009. Aircraft Characteristics (December 2009), <https://www.faa.gov/airports/engineering/aircraft_char_database/> 